scale manometer connected through a fine tube to a small vessel containing helium in the liquefaction space. The apparatus cost approximately $£ 30$. Since there is no need to recompress the helium rapidly, a small cheap compressor is sufficient.

The liquid hydrogen required is produced in a plant of the standard pattern designed in the Physico-Chemical Institute in Berlin whicb has been in use at Oxford for some years now without giving any trouble. Impurities in the hydrogen are condensed by a preliminary expansion and continuously removed by a slow stream of hydrogen. With a compressor capable of dealing with ten cubic metres of free gas an hour and an expenditure of approximately $1 \cdot 4$ litres of liquid nitrogen per litre of liquid hydrogen, this plant produces some $2 \frac{1}{2}$ litres of liquid hydrogen per hour. Liquefier and compressor together cost approximately $£ 350$.

The liquid hydrogen is stored in pyrex Dewar flasks silvered and exhausted in the laboratory. As their efficiency equalled that claimed for the more complicated double vessels developed by Prof. Kapitza, they have been retained.

If low temperature work expands and a large number of experiments are in hand simultaneously, it may be necessary to consider the use of the continuous linde process of liquefaction. In view of the cost of the gas and the precautions necessary for its recovery, its distribution involves considerable inconvenience, which for the time being are scarcely worth facing. The mere liquefaction, of course, offers no difficulties and there is little doubt that the Berlin type of apparatus, which is already in use in many laboratories, will prove as serviceable and efficient as the hydrogen liquefier, should it ever be necessary to change over to this system.

Finally, a word of thanks is due to Dr. Mendelssohn, who kindly brought the liquefier over from Breslau and placed all his knowledge and experience unreservedly at the disposal of the department. But for this, it would scarcely have been possible to obtain, without hitch or trouble, liquid helium within one week of the arrival of the apparatus in Oxford.

\title{
Metrology by Light Waves at the National Physical Laboratory*
}

$\mathrm{I}^{\mathrm{N}}$ 1923 the International Committee of Weights and Measures accepted the eventual use of a wave-length of light as the ultimate standard of length. Already in the previous year the Board of Trade had recognised the need of replacing the existing Imperial standard yard by a standard more in accord with modern requirements. For these reasons it was decided that the National Physical Laboratory should establish means of realising a wave-length standard of length and with it determine the length of the Imperial standard yard in terms of that wave-length.

The paper cited below, by Messrs. J. E. Sears, Jr., and $\mathrm{H}$. Barrell, gives an account of the apparatus and methods which complete the first stage of this programme.

The new apparatus is of the type used by Benoit, Fabry and Perot, but is distinguished from the two previously existing instruments of this type in very many features of design. The more important new characteristics of the apparatus result from two radical departures from what was aimed at in the earlier instruments.

In the first place, Benoît, Fabry and Perot compared their optically determined metre etalon with a line standard by the usual methods of microscope observations, with the aid of fine lines scribed on the polished edges of the terminal glass plates of the metre etalon; the prototype metre being a line standard, such procedure was unavoidable at some stage of the work. In contradistinction to this, the apparatus at the National Physical Laboratory derives the length of an end standard directly from the length of the metre

* "A New Apparatus for Determining the Relationship Between Wave-Lengths of Light and the Fundamental Standards of Length", by J. E. Sears and H. Barrell, Phil. Trans. Roy. Soc., A, vol. 231 pp. 75-145. Sept. 16, 1932. etalon by optical interference, the ends of the etalon being polished parallel to a high optical precision by the Pitter Gauge and Precision Tool Co. of Woolwich by a technique worked out at the Laboratory in 1920. This procedure avoids one of the most difficult steps in the earlier workthe correlation of the positions of the reflecting surfaces of the metre etalon with those of the graduation lines.

Secondly, the new apparatus is so designed that measurements may be made either in air under controlled conditions, or in vacuum, and it thus makes possible new determinations of the refractive index of the air under various atmospheric conditions, which in any event will be needed before a wave-length definition of unit of length can be finally adopted for measurements of the highest precision. Measurements of this kind involve the observation of such variable factors as temperature, barometric pressure, humidity and possibly even carbon dioxide content of the air, and there are disagreements among the published values of the effects of these factors on the refractive index of the air.

It may be also noted here that the separation of the plates in the etalon which is used for the initial measurement has been increased from the $1 / 16 \mathrm{~m}$. used in the two earlier instruments to 1/12 m., thereby leading to a greater relative accuracy in the basic measurement.

Although the above-mentioned new features of design are in principle the most important, those interested in the design of instruments will perhaps derive most pleasure in considering other details. The apparatus is characterised by a full envisagement of what functions were to be carried out and an adequate provision of means for their convenient 
and certain execution: one gets the impression that in using the apparatus there will be no need for successive trials in order that an essential adjustment or observation may be secured. Two examples of this must suffice.

One of the difficulties in theconstruction of etalons for such an apparatus is in securing that the lengths are exact multiples of the shortest one. Instead of relying on trial and error polishing of the ends, the etalons at the National Physical Laboratory are adjusted by four strain wires symmetrically disposed around the etalon, by means of which changes in length of any etalon of so much as 1 part of 25,000 can with certainty be produced without exceeding the elastic limit of the strain wires.
Again, not only must the supporting mechanism of the longest etalon be capable of the very accurate parallel displacements which are necessary, but such displacements must also be made with certainty and convenience and without varying the distribution of load on the supporting pillar and so forth. The means whereby this manipulation is secured are worthy of special attention.

It is a matter for great satisfaction that the Board of Trade together with the National Physical Laboratory decided to place metrology in the British Empire on a wave-length basis; and the designers and the workshop personnel of the National Physical Laboratory are to be congratulated on the successful completion of the first part of the programme.

\section{Obituary}

Lieut.-Col. J. Stephenson, C.I.E., F.R.S.

$\mathrm{W}^{\mathrm{B}}$ regret to announce the death, which occurred in London on February 2, of Lieut.-Col. John Stephenson. He was born in 1871 at Padiham, Lancashire, and was educated at the Burnley Grammar School and the University of Manchester, where he had a distinguished career as a student in science and in medicine. After graduating, he acted as housesurgeon in the Manchester Royal Infirmary and in the London Hospital for Diseases of the Chest. In 1895 he was appointed to the Indian Medical Service and for the next five years was on military duty, including service in the North West Frontier Expedition of 1897. During the following years he was on plague duty and held various appointments as civil surgeon in the Punjab until in 1906 he became professor of biology in Government College, Lahore, of which he was appointed principal in 1912.

In Manchester, Stephenson had studied zoology for two years under the stimulating influence of Prof. Milnes Marshall, and with this foundation he instituted in Lahore instruction in the subject which reached a high standard and within a few years resulted in a productive school of zoology. Several of the students from his laboratories, whom he inspired with his own ideals of critical work and with the need for the investigation of the fauna of their country, are now holding influential zoological posts in India and have published important papers on their researches. His tenure of office in Lahore was marked by conspicuous success as a teacher and by high administrative qualities, and his quiet, effective personality left a deep and lasting impression on his students.

Stephenson resigned his post in Lahore in 1920 and I was fortunate in being able to attract him to the University of Edinburgh, in which he was appointed lecturer in zoology, to share in conducting the courses on invertebrates for senior students. His teaching was clear and concise, with a wide scientific outlook, and he was unsparing in giving help and encouragement, especially to those who were reading for honours in zoology. In Lahore, immediately after taking up his duties, Stephenson began investigations on the aquatic oligochætes of the Punjab and during the next ten years published a series of papers on these worms. His interests then widened to the oligochætes in general and he examined numerous collections from various parts of India. These studies were continued with great assiduity in Edinburgh and in 1923 he published the important volume on the oligochætes in "The Fauna of British India" and became recognised as one of the two chief authorities on the order. Before he resigned his lectureship in Edinburgh in 1929, he completed the masterly monograph on the Oligochæta which was published early in 1930 by the Clarendon Press. Stephenson's mastery of the structure and classification of oligochætes, his extensive knowledge of the literature and his flair for conciseness and clearness in presenting facts and conclusions, enabled him to produce a monograph of exceptional merit which contains also conclusions of general interest; for example, on the bearing of the known facts of geographical distribution on the former existence of a more extensive antarctic continent and of Indo-Australian and other landbridges, on convergence and on polyphyly. Stephenson was appointed in 1928 editor of "The Fauna of British India" in succession to the late Sir Arthur Shipley.

On leaving Edinburgh in November, 1929, Stephenson went to reside in London and continued his investigations on oligochætes as an unofficial worker in the Natural History Museum until about two months ago. Two years ago he became zoological secretary of the Linnean Society and took an active part in its affairs.

Stephenson was the author during the last twenty-seven years of numerous papers on Oligochæta. His contributions to the advancement of knowledge were recognised by the award in 1920 of the Keith Medal of the Royal Society of 